ISSN: 1410-8917

Jurnal Kimia Sains \& Aplikasi

e-ISSN: 2597-9914

\section{Jurnal Kimia Sains dan Aplikasi Journal of Scientific and Applied Chemistry}

Journal homepage: http://ejournal.undip.ac.id/index.php/ksa

\title{
Adsorption of HDTMA-Br Surfactant with Concentration Variation by Rice Husk-Based Activated Carbon Produced by Variation of Carbonization Temperature
}

\author{
Galih N. R. Pargiman ${ }^{a}$, Arnelli ${ }^{\mathrm{a},{ }^{*}}$, Yayuk Astuti ${ }^{\mathrm{a}, *}$ \\ ${ }^{a}$ Chemistry Department, Faculty of Sciences and Mathematics, Diponegoro University, Jalan Prof. Soedarto, Tembalang, Semarang \\ * Corresponding author: arnelli@live.undip.ac.id; yayuk.astuti@live.undip.ac.id
}

https://doi.org/10.14710/jksa.21.4.171-174

\section{Article Info \\ Article history: \\ Received: 3 August 2018 Revised: 12 October 2018 Accepted: 14 October 2018 Online: 31 October 2018}

Keywords:

Activated carbon, Hexadecyltrimethyl ammonium bromide, surfactant, adsorption

\section{Abstract}

Research has been conducted on the adsorption of HDTMA-Br surfactant by rice huskactivated carbon with variation of carbonization temperature and concentration of HDTMA$\mathrm{Br}$. This study aims to produce surfactant modified activated carbon (SMAC), therefore it is necessary to determine the influence of carbonization temperature to the adsorption capability of activated carbon on HDTMA-Br surfactant by identifying the amount of HDTMA$\mathrm{Br}$ surfactant absorbed, to characterize the characters of carbon, activated carbon and activated carbon adsorbing surfactant using FTIR and SAA. Carbonization was carried out by pyrolysis with temperature variations of 300,350 and $400^{\circ} \mathrm{C}$. The carbon produced was activated using $60 \% \mathrm{H}_{3} \mathrm{PO}_{4}$ for 1 hour. After that, the activated carbon was applied to adsorb HDTMA-Br surfactant by varying the concentration that were 300, 1100, 1900, 2700, 3500 and $4300 \mathrm{ppm}$. The results showed that HDTMA-Br adsorbed tended to increase by increasing the concentration of surfactant. In addition, the best carbonization temperature showing high adsorption capability of activated carbon was at $300^{\circ} \mathrm{C}$. FTIR spectra of activated carbon showed the presence of $\mathrm{P}=\mathrm{O}$ peak; at the SMAC sampel there was peak of $\mathrm{N}-\left(\mathrm{CH}_{3}\right)_{3}$ with different intensities in three samples. Moreover, SAA analysis showed that the surface area of activated carbon increased compared to carbon and slightly decreased after the activated carbon absorbed HDTMA-Br.

\section{Abstrak}

Telah dilakukan penelitian tentang adsorpsi surfaktan HDTMA-Br oleh karbon aktif dengan variasi temperatur karbonisasi dan konsentrasi HDTMA-Br berbahan dasar sekam padi. Penelitian ini bertujuan untuk membuat karbon aktif termodifikasi surfaktan (SMAC), untuk itu perlu ditentukan pengaruh temperatur karbonisasi terhadap kemampuan adsorpsi karbon aktif pada surfaktan HDTMA-Br melalui jumlah surfaktan yang terserap, menentukan karakteristik karbon, karbon aktif dan karbon aktif yang telah mengadsorpsi surfaktan dengan FTIR dan SAA. Karbonisasi dilakukan dengan tiga variasi temperatur pirolisis yaitu 300,350 dan $400^{\circ} \mathrm{C}$. Karbon yang dihasilkan diaktivasi menggunakan $\mathrm{H}_{3} \mathrm{PO}_{4} 60 \%$ selama 1 jam. Kemudian, karbon aktif yang terbentuk digunakan untuk mengadsorpsi surfaktan HDTMABr dengan variasi konsentrasi 300, 1100, 1900, 2700, 3500, dan 4300 ppm. Hasil penelitian menunjukkan bahwa HDTMA-Br teradsorpsi cenderung meningkat dengan meningkatnya konsentrasi dan temperatur karbonisasi yang baik adalah $300^{\circ} \mathrm{C}$. Spektra FTIR dari karbon aktif terlihat adanya puncak $\mathrm{P}=\mathrm{O}$ dan pada $\mathrm{SMAC}$ terdapat puncak $\mathrm{N}-\left(\mathrm{CH}_{3}\right)_{3}$ dengan intensitas yang berbeda diantara ketiga sampel dan analisis SAA menunjukkan luas permukaan karbon aktif meningkat dibandingkan karbon dan sedikit turun setelah karbon aktif tersebut menyerap HDTMA-Br. 


\section{Pendahuluan}

Karbon aktif dapat dibuat dari bahan yang mengandung material organik dengan kandungan karbon yang tinggi [1-3]. Karbon aktif dapat dibuat dari sekam padi karena harganya yang murah dan kandungan material organiknya yang banyak [3, 4].

Proses pengolahan sekam padi menjadi karbon aktif melalui beberapa tahapan yaitu meliputi karbonisasi dan aktivasi. Sekam padi dapat dikarbonisasi dengan metode pirolisis, yaitu proses dekomposisi biomassa pada temperatur tinggi tanpa adanya oksigen sehingga karbon yang dihasilkan lebih banyak. Kondisi pirolisis dapat diatur sesuai dengan kebutuhan, misalnya temperatur reaktor [5]. Pada penelitian Naqvi, dkk. [6] tentang pengaruh temperatur pirolisis terhadap jumlah karbon yang dihasilkan dengan variasi temperatur pirolisis $350^{\circ} \mathrm{C}$ sampai $600^{\circ} \mathrm{C}$ dan diperoleh temperatur yang paling banyak menghasilkan kadar karbon yang paling tinggi adalah temperatur $450^{\circ} \mathrm{C}$.

Aktivator yang digunakan dalam pembuatan karbon aktif dapat berupa aktivator asam, basa, dan netral [4]. Metode yang sering digunakan mengaktivasi yaitu dengan aktivator asam. Aktivator asam yang digunakan untuk penelitian ini adalah $\mathrm{H}_{3} \mathrm{PO}_{4}$. Pada proses aktivasi, larutan $\mathrm{H}_{3} \mathrm{PO}_{4}$ akan meresap masuk kedalam kisi-kisi plat karbon dan akan mengeluarkan senyawa-senyawa pengotor sehingga pori-pori karbon akan bertambah besar [7]. Reskiandini [8] melaporkan dalam penelitiannya bahwa pengaktivasian karbon dari sekam padi menggunakan $\mathrm{H}_{3} \mathrm{PO}_{4}$ pada temperatur $420^{\circ} \mathrm{C}$ memiliki efisiensi adsorpsi terhadap surfaktan sodium lauryl sulphat (SLS) lebih besar yaitu $89,4 \%$ dibandingkan karbon dengan pengaktivan pada temperatur $25^{\circ} \mathrm{C}$ hanya sebesar $51,8 \%$. Lin, dkk. [9] menyatakan, pada konsentrasi surfaktan HDTMA-Br di atas konsentrasi misel kritis (CMC) kemampuan adsorpsi surfaktan akan meningkat dengan konsentrasi optimum $3500 \mathrm{ppm}$.

Adsorpsi surfaktan oleh karbon aktif bertujuan untuk memodifikasi karbon aktif sehingga akan terbentuk material baru yaitu SMAC (Sufactant Modified Active Carbon). SMAC mempunyai keunggulan sebagai adsorben yang lebih spesifik dari karbon aktif, di mana SMAC diaplikasikan untuk adsorben kation logam berat atau anion yang berbahaya di perairan karena surfaktan dapat merubah permukaan karbon aktif menjadi lebih polar dan bermuatan tergantung kepada surfaktan yang digunakan [10]. Dari penelitian yang telah dikemukakan di atas maka proses karbonasi sekam padi untuk mendapatkan karbon dilakukan pada temperatur berbeda yaitu $300,350,400^{\circ} \mathrm{C}$ dan surfaktan yang diadsorpsi adalah HDTMA- $\mathrm{Br}$ dengan variasi konsentrasi yaitu 300, 1100, 1900, 2700, 3500 dan $4300 \mathrm{ppm}$.

\section{Metode Penelitian}

Bahan

Bahan-bahan yang digunakan dalam penelitian ini adalah sekam padi, aquades, bromophenol blue, buffer pospat $\mathrm{pH} 8$, kloroform, $\mathrm{H}_{3} \mathrm{PO}_{4}, \mathrm{NaOH} 0,1 \mathrm{M}$. Semua bahan yang digunakan dalam penelitian ini merupakan bahanbahan pro analysis.

\section{Preparasi Sampel Karbon Aktif}

Karbonisasi sekam padi menggunakan metode pirolisis dengan variasi temperatur karbonisasi $300^{\circ} \mathrm{C}$, $350^{\circ} \mathrm{C}$ dan $400^{\circ} \mathrm{C}$. Karbon yang dihasilkan kemudian diaktivasi menggunakan $\mathrm{H}_{3} \mathrm{PO}_{4} 60 \%$ pada temperatur $420^{\circ} \mathrm{C}$ selama 1 jam [11].

\section{Modifikasi Karbon Aktif dengan Surfaktan}

Sebanyak 1 gram karbon aktif dikontakkan dengan surfaktan $25 \mathrm{~mL}$ surfaktan HDTMA-Br dengan variasi konsentrasi 300; 1100; 1900; 2700; 3500 dan 4300 ppm selama 5 jam kemudian disaring.

\section{Penentuan Konsentrasi Surfaktan yang tidak terserap}

Penentuan konsentrasi surfatan yang tidak terserap dilakukan dengan metode pengkompleksan bromophenol blue [12].

\section{Karakterisasi}

Sampel karbon, karbon aktif dan karbon aktif yang telah menyerap surfaktan paling banyak pada masingmasing temperatur karbonisasi dikaraterisasi menggunakan spekrofotometer Infra Merah (FTIR) dan Surface Area Analyzer (SAA).

\section{Hasil dan Pembahasan}

\section{Pengaruh Temperatur Karbonisasi dan Konsentrasi Surfaktan}

Penambahan aktivator $\mathrm{H}_{3} \mathrm{PO}_{4} \quad 60 \%$ dapat meningkatkan luas permukaan karbon sehingga kemampuan daya serap dari karbon akan meningkat. Karbon aktif yang telah terbentuk dikontakkan dengan surfaktan HDTMA-Br sehingga akan menjadi karbon aktif yang telah menyerap surfaktan yang berguna untuk menyerap ion-ion spesifik di perairan.

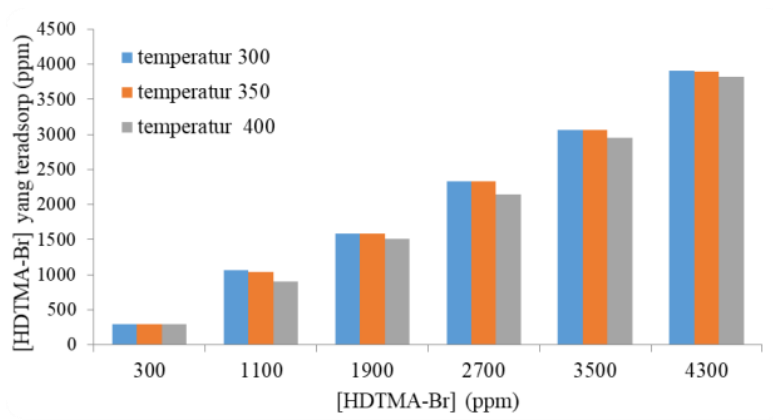

Gambar 1 Pengaruh penambahan konsentrasi HDTMABr terhadap konsentrasi HDTMA-Br yang teradsorp 
Berdasarkan Gambar 1 terlihat adanya peningkatan daya serap karbon aktif seiring dengan penambahan konsentrasi surfaktan pada temperatur karbonisasi $300^{\circ} \mathrm{C}, 350^{\circ} \mathrm{C}$ dan $400^{\circ} \mathrm{C}$. Pada temperatur karbonisasi $300^{\circ} \mathrm{C}$ terlihat paling banyak mengadsorpsi surfaktan yaitu sebesar 3911,1 ppm pada konsentrasi surfaktan 4300 ppm. Pada temperatur $350^{\circ} \mathrm{C}$ terjadi penurunan adsorpsi surfaktan sebesar $0,28 \%$, sedangkan temperatur $400^{\circ} \mathrm{C}$ terjadi penurunannya $2,3 \%$.

Peningkatan kemampuan adsorpsi seiring dengan bertambahnya konsentrasi surfaktan ini dimungkinkan karena pada karbon aktif yang menggandung gugus $\mathrm{P}=\mathrm{O}$ (Gambar 2) di mana gugus $\mathrm{P}=\mathrm{O}$ diperkirakan situs aktif dalam menyerap misel surfakatan yang sudah terbentuk pada saat membuat larutan surfaktan, sehingga permukaan karbon aktif akan membentuk bilayer. Selain itu juga, seiring dengan peningkatan jumlah dan konsentrasi surfaktan yang digunakan maka interaksi yang terjadi pada permukaan karbon aktif akan semakin meningkat pula, karena semakin banyaknya surfaktan yang menempel pada permukaan karbon aktif dan membentuk bilayer [13].

\section{Karakterisasi menggunakan Spektrofotometer FTIR}

Karakterisasi menggunakan spektrofotometer FTIR berfungsi untuk mengetahui gugus fungsi pada masingmasing sampel

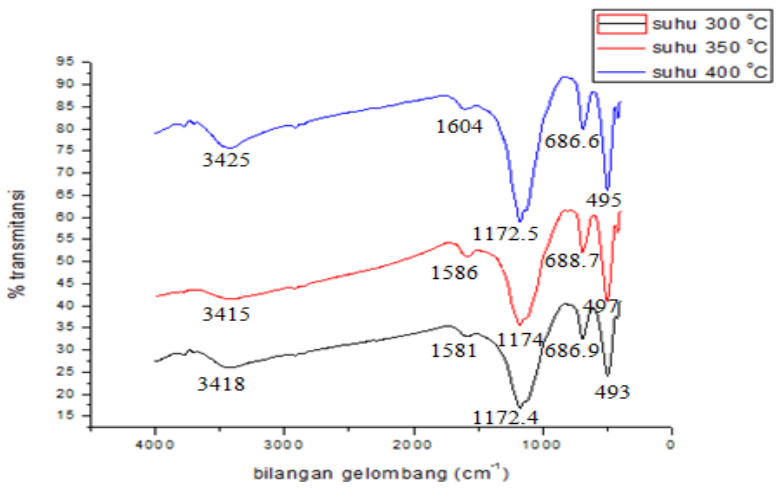

Gambar 2 Spektra FTIR karbon aktif yang telah menyerap surfaktan dengan variasi temperatur karbonisasi

Gambar 2 merupakan spektra FTIR karbon aktif yang sudah dikontakkan dengan surfaktan HDTMA-Br 4300 ppm dengan variasi suhu karbonisasi. Pada ketiga SMAC muncul puncak kisaran $2920 \mathrm{~cm}^{-1}$ yang menunjukkan adanya regangan $\mathrm{CH}_{3}-\mathrm{R}$, selain itu ketiga SMAC juga muncul puncak kisaran $1500 \mathrm{~cm}^{-1}$ yang menunjukkan adanya $\mathrm{CH}_{3}$ dari $\mathrm{N}-\left(\mathrm{CH}_{3}\right)_{3}$ yang berasal dari surfaktan HDTMA-Br [14].
Tabel 1 Luas area\% transmitansi SMAC pada masingmasing suhu karbonisasi

\begin{tabular}{ccc}
\hline $\begin{array}{c}\text { Gugus yang } \\
\text { muncul }\end{array}$ & $\begin{array}{c}\text { Suhu } \\
\text { Karbonisasi }\left({ }^{\circ} \mathrm{C}\right)\end{array}$ & Luas Area \% T \\
\hline $\mathrm{N}-\left(\mathrm{CH}_{3}\right)_{3}$ & 300 & 298,16 \\
& 350 & 387,59 \\
& 400 & 429,11 \\
\hline
\end{tabular}

Berdasarkan Tabel 1 menunjukkan bahwa semakin tinggi suhu karbonisasi maka surfaktan HDTMA-Br semakin banyak terserap. Gugus-gugus yang telah ditemukan dari masing- masing panjang gelombang dapat disimpulkan bahwa karbon sebelum aktivasi tidak ditemukan gugus $\mathrm{P}=\mathrm{O}$, setelah diaktivasi dengan $\mathrm{H}_{3} \mathrm{PO}_{4}$ muncul gugus $\mathrm{P}=\mathrm{O}$ pada bilangan gelombang sekitar $1172-1174 \mathrm{~cm}^{-1}$ yang berasal dari aktivator $\mathrm{H}_{3} \mathrm{PO}_{4}$, setelah ditambahkan surfaktan HDTMA-Br muncul gugus $\mathrm{CH}_{3}$ dari N-( $\left(\mathrm{CH}_{3}\right)_{3}$ yang berasal dari surfaktan HDTMA-Br.

\section{Karakterisasi menggunakan SAA}

Karakterisasi SAA digunakan untuk mengetahui luas permukaan, volume pori dan yang dianalisis dengan SAA ini adalah karbon, karbon aktif dan SMAC pada konsentrasi awal HDTMA-Br 4300 ppm (Tabel 1). Tabel 1 memperlihat terjadi peningkatan luas permukaan dari karbon menjadi karbon aktif setelah diaktivasi menggunakan $\mathrm{H}_{3} \mathrm{PO}_{4}$, kemudian luas permukaan untuk karbon aktif yang telah menyerap surfaktan juga meningkat setelah ditambahkan surfaktan HDTMA-Br dibandingkan karbon. Peningkatan luas area tersebut dapat meningkatkan kemampuan adsorbsi dari karbon aktif, sebagaimana digambarkan pada Tabel 2.

Tabel 2. Hasil analisis luas area pada karbon, karbon aktif dan karbon aktif yang telah menyerap surfaktan

\begin{tabular}{lccc}
\hline \multicolumn{1}{c}{ Sampel } & $\begin{array}{c}\text { Temperatur } \\
\left({ }^{\circ} \mathrm{C}\right)\end{array}$ & $\begin{array}{c}\text { Luas } \\
\text { permukaan } \\
\left(\mathrm{m}^{2} / \mathrm{g}\right)\end{array}$ & $\begin{array}{c}\text { Volume pori } \\
(\mathrm{cc} / \mathrm{g})\end{array}$ \\
\hline karbon & 300 & 1,937 & 0,012 \\
& 350 & 1,110 & 0,010 \\
karbon aktif & 400 & 2,146 & 0,013 \\
& 300 & 15,039 & 0,049 \\
Karbon aktif & 350 & 22,499 & 0,052 \\
setelah & 400 & 18,078 & 0,045 \\
menyerap & 350 & 14,141 & 0,049 \\
surfaktan & 400 & 15,309 & 0,074 \\
\hline
\end{tabular}

Peningkatan luas permukaan dan volum pori dari karbon menjadi karbon aktif, dikarenakan peran $\mathrm{H}_{3} \mathrm{PO}_{4}$ dalam proses aktivasi yang dapat membantu mengeluarkan pengotor sehingga pori karbon semakin terbuka dan luas permukaan karbon bagian dalam (Internal Surface) semakin meningkat. SMAC juga mempunyai luas permukaan dan volum pori lebih besar dibandingkan karbon. Luas permukaan SMAC menurun pada suhu karbonisasi 300 dan $350^{\circ} \mathrm{C}$ dibandingkan 
karbon aktif, dapat dijelaskan bahwa sebagian molekul HDTMA-Br menutupi permukaan karbon aktif. Hal ini terlihat dari efisiensi adsorpsi HDTMA-Br pada konsentrasi awal 4300 ppm oleh karbon aktif (lihat Tabel 3).

Tabel 3. Efisiensi Adsorpsi Surfaktan HDTMA-Br oleh karbon aktif

\begin{tabular}{cccc}
\hline $\begin{array}{c}\text { Suhu } \\
\text { karbonisasi }\left({ }^{\circ} \mathrm{C}\right)\end{array}$ & $\begin{array}{c}\text { Efisien } \\
\text { Adsorpsi }(\%)\end{array}$ & $\begin{array}{c}\text { Luas permukaan } \\
(\mathrm{m} 2 / \mathrm{g})\end{array}$ & $\begin{array}{c}\text { Volume } \\
\text { pori }(\mathrm{cc} / \mathrm{g})\end{array}$ \\
\hline 300 & 90,9 & 14,141 & 0,049 \\
350 & 90,7 & 15,309 & 0,078 \\
400 & 88,8 & 26,062 & 0,066 \\
\hline
\end{tabular}

Tabel 3 memperlihat bahwa efisiensi adsorpsi HDTMA-Br oleh karbon aktif dengan suhu karbonisasi $300^{\circ} \mathrm{C}$ dan $350^{\circ} \mathrm{C}$ hampir sama dan luas permukaan SMAC juga tidak jauh berbeda. SMAC (suhu karbonisasi $400^{\circ} \mathrm{C}$ ) memiliki luas permukaan yang besar sebanding dengan HDTMA-Br yang terserap, karena karbon aktif menyerap HDTMA-Br lebih rendah sehingga ada permukan karbon aktif yang masih kosong. Luas permukaan SMAC yang cukup besar dan permukaan SMAC bermuatan posittif maka memungkinkan SMAC dipakai untuk adsorben anion.

\section{Kesimpulan}

Adsorpsi surfaktan oleh karbon aktif semakin menurun dengan meningkatnya temperatur karbonisasi. Penambahan konsentrasi surfaktan menunjukkan kecenderungan peningkatan surfaktan yang terserap dengan nilai peningkatan rata-rata pada karbonisasi temperatur $300^{\circ} \mathrm{C}$ sebesar $36 \%$. Peningkatan kecenderungan juga bisa dilihat pada karbonisasi temperatur $350^{\circ} \mathrm{C}$ dan $400^{\circ} \mathrm{C}$. penambahan aktivator, dan pengontakkan dengan surfaktan.

\section{Ucapan Terima Kasih}

Seluruh penulis mengucapkan terima kasih kepada RISTEK DIKTI yang telah memberikan dana penelitian melalui skim Penelitian Fundamental pada tahun 2016.

\section{Daftar Pustaka}

[1] Ratu Yulia Akhsanti, Retno Ariadi Lusiana, Khabibi Khabibi, Pemanfaatan Karbon Aktif Serbuk Gergaji Kayu Jati untuk Menurunkan Chemical Oxygen Demand (COD) Limbah Cair Industri Tekstil, Jurnal Kimia Sains dan Aplikasi, 13, 2, (2010) 66-70

[2] Feti Dwi Kurniati, Pardoyo Pardoyo, Suhartana Suhartana, Sintesis Arang Aktif dari Tempurung Kelapa dan Aplikasinya Untuk Adsorpsi Asap Cair, Jurnal Kimia Sains dan Aplikasi, 14, 3, (2011) 72-76

[3] Arunrat Cheenmatchaya, Sukjit Kungwankunakorn, Preparation of activated carbon derived from rice husk by simple carbonization and chemical activation for using as gasoline adsorbent, International Journal of Environmental Science and Development, $\quad 5, \quad 2, \quad$ (2014) 171 http://dx.doi.org/10.7763/IJESD.2014.V5.472
[4] Diana Nur Al-Latief, Arnelli, Yayuk Astuti, Synthesis of sodium lauryl sulphate (SLS)-modified activated carbon from risk husk for waste lead $(\mathrm{Pb})$ removal, AIP Conference Proceedings, (2015) 060017 https://doi.org/10.1063/1.4938371

[5] Anchan Paethanom, Kunio Yoshikawa, Influence of pyrolysis temperature on rice husk char characteristics and its tar adsorption capability, Energies, 5, 12, (2012) 4941-4951 http://dx.doi.org/10.3390/en5124941

[6] Salman Raza Naqvi, Yoshimitsu Uemura, Noridah Binti Osman, Suzana Yusup, Mohd Fadhil Nuruddin, Physiochemical properties of pyrolysis oil derived from fast pyrolysis of wet and dried rice husk in a free fall reactor, Applied Mechanics and Materials, 625, (2014) 604-607 https://doi.org/10.4028/www.scientific.net/AMM.62 5.604

[7] Abdul Ghafur, Mintarlis, Pembuatan Arang Aktif Dari Limbah Padat Sintesis Furfural Berbahan Dasar Sekam Padi Melalui Aktivasi Kimia, UNESA Journal of Chemistry, 3, 3, (2014) 1-8

[8] Dewi Reskiandini, Aktivasi Karbon dari Sekam Padi Menggunakan Aktivator $\mathrm{H}_{3} \mathrm{PO}_{4}$ Sebagai Bahan Pembuat Karbon Aktif Termodifikasi Surfaktan (SMAC) untuk Adsorpsi $\mathrm{Pb}_{2+}$, Diponegoro University, Semarang

[9] Shu-Ying Lin, Wei-fang Chen, Ming-Tao Cheng, Qian Li, Investigation of factors that affect cationic surfactant loading on activated carbon and perchlorate adsorption, Colloids and Surfaces A: Physicochemical and Engineering Aspects, 434, (2013) 236-242

https://doi.org/10.1016/j.colsurfa.2013.05.048

[10] Eko Tri Sumarnadi Agustinus, Anggoro Tri Mursito, Happy Sembiring, Peningkatan daya serap karbon aktif terhadap ion logam hexavalent chromium (CrVI) melalui modifikasi dengan cationic surfactant (ethylinediamine), RISET Geologi dan Pertambangan, $23,1,(2013) 15-26$

[11] Mamdoh R. Mahmoud, Gehan E. Sharaf El-deen, Mohamed A. Soliman, Surfactant-impregnated activated carbon for enhanced adsorptive removal of $\mathrm{Ce}(\mathrm{IV})$ radionuclides from aqueous solutions, Annals of Nuclear Energy, 72, (2014) 134-144 https://doi.org/10.1016/j.anucene.2014.05.006

[12] Widajanti Wibowo, Tresye Utari, Rika Tri Yunarti, Anion exchange capacity of chromate on modified zeolite clinoptilolite with HDTMA-Br and its regeneration, Makara Journal of Science, 15, 1, (2011) 53-57 https://doi.org/10.7454/mss.v15i1.878

[13] Retno Agnestisia, Noer Komari, Sunardi Sunardi, Adsorpsi Fosfat $\left(\mathrm{PO}_{4^{3-}}\right)$ Menggunakan Selulosa Purun Tikus (Eleocharis dulcis) Termodifikasi Heksadesiltrimetilammonium Bromida (HDTMABr), Jurnal Sains dan Terapan Kimia, 6, 1, (2016) 71-86

[14] U Aroke, U El-Nafaty, XRF, XRD and FTIR properties and characterization of HDTMA-Br surface modified organo-kaolinite clay, International Journal of Emerging Technology and Advanced Engineering, 4, 4, (2014) 817-825 